\title{
Tracing Path: From Conserved/ Museum towards Vivid City- Role of Urban Design
}

\author{
Miodrag Ralevic ${ }^{1}$, Tatjana Mrdjenovic ${ }^{2, *}$, Džemila Beganović ${ }^{1}$, Esad Muminović ${ }^{3}$ \\ ${ }^{1}$ Faculty for Technical Sciences, State University of Novi Pazar, Serbia \\ ${ }^{2}$ Faculty of Architecture, University of Belgrade, Serbia \\ ${ }^{3}$ Faculty of Technical Sciences, University of Pristina, Serbia
}

Received June 19,2019; Revised July 23, 2019; Accepted August 10, 2019

Copyright $(2019$ by authors, all rights reserved. Authors agree that this article remains permanently open access under the terms of the Creative Commons Attribution License 4.0 International License

\begin{abstract}
The relation to the "historical city" can have two contradictory goals, ie. the tendency to form two opposing contradictory models: on the one hand, the preservation of all levels of values shows and proves its priori historicity, which in the final form manifests itself in obtaining the character of a museum model, where the historical city turns into an exhibit of the time in which it was created and which reflects the civilization in which it originated; on the other hand, the need for their socio-economic development, especially in relation to gentrification, tourism development introduces new activities. Both models should not be seen as separate or opposing, but the way to preserve the "historic" of the city as a base value should be discovered, and enable it to attract and live its "history", evolving and changing on the principles of the time in which it was created, accepted and adapted to the cultural needs of the time it should take. The aim of the paper is to make relations between relevant theories resulting in principles of tracing relation between two models taking into account Landry's concept of Creative city, and Castells's theory of Project identity, Healey's Collaborative theory, Mrdjenovic's Integrative game of urban design using method of comparative analyses between theories and case study analysis. The hypothesis of the research is that urban design can be an integrative discipline that evokes historical cities to become vivid and livable. The research will result in principles for urban design that can trace a path form museum to vivid city.
\end{abstract}

Keywords Historical City, Creative City, Project Identity Vivid City, Participation, Game Theory

\section{Introduction}

What is meant by the definition and meaning of historical cities? Are not all the cities that are "lasting" in fact, "historical cities" that were simultaneously adapting to "novelties" (technological, social changes ...) fighting for the preservation of their identity? The cities' struggle for preservation of the identity was facilitated by their physical creation, in which each original materialization, carried the impossibility of changing its physical structure, providing resistance to any conquerors.

Therefore, the aim of the research is describing the extended role of urban design in sustainable urban regeneration of protected urban ambient historical cities. Contemporary urban regeneration implies the creation of sustainable places by affirmation and promotion of local characteristics. The assumption is that integral urban design can generate sustainable spatial-program solutions and create integral space as a subject of sustainable urban regeneration. The thesis of the work is that urban design is considered as a process which assumes a leading role in urban regeneration. Such a process plays the role of forming integral space, respecting and advocating local identity and cultural values, in accordance with the environmental principles of space organization and construction, while providing social cohesion, the development of cultural tourism and commercial sector through institutional sustainability. The aim of this work is the description of the participative process in generating integral spatial-program solutions for urban design of the public space of the Bač Fortress Suburbium. The expected result of this research is the definition of the principles urban design for regeneration of historical cities.

Sustainable development of protected urban ambient historical cities defines the framework for their regeneration, while including them responsibly into the contemporary socio-economic trends. Integral development as an equivalent of sustainability implies simultaneously the preservation of non-renewable resources, such as the urban cultural heritage, as well as enabling its development with positive externalities on 
other development sectors. "Integrative urban planning wants to cease with the fragmentation of our landscapes and our lives by using activist design solutions. Strongly refusing to idealize the past or to cowardly avoid the present, integral urban plan attempts to resist the divisions in urban and social structures, pointing to contemporary challenges and formulating inspirational alternatives for a wealthier tomorrow." [1]. This research will discuss and test on a practical example the extended role of urban design, to be an integrating instrument in the urban regeneration processes and provide a holistic development of these ambient. Understood as a process of space creation, urban design with its different process dimensions, from subjective-expressive, multi-disciplinary to socio-collaborative, can offer creative solutions in the regeneration process and globalization challenges.

The complexity of the globalization process introduces the story of identity as the pillar of socio-economic development, therefore changing the focus on the urban planning and design relation in the context of urban regeneration. In a global society, the power of local identity is becoming very strong in the global market race. Castells defines several areas of urban objectives that encourage the preservation and development of local identity: "... urban demands on living conditions and collective consumption; the affirmation of local cultural identity; and the conquest of local political autonomy and citizen participation." [2]. Urban design as the advocate of multi-dimensional factors in the quality of place [3] represents a framework in the regeneration and creation of integral space. Its artistic dimension qualifies it for the re-examination of its role as the dominant discipline in the urban regeneration process. Understood as a decision-making process, it can create a framework for the regeneration and integration of the sustainability dimension, through the creation of a global identity and space. This also justifies one of the research opinions, which will be discussed in this paper.

Sustainable approach to urban regeneration creates a balance between the protection and development of local identities, including them responsibly into the global trends as the pillars of socio-economic development. The simultaneous need for the protection of inherited values, and the development of new ones, stresses the importance of an integral approach. At the same time, it implies the preservation of non-renewable resources, such as urban cultural heritage, as well as facilitation in the development of new ambient values. Such an approach combines the concepts of space with different development paradigms (economic, social, physical, divided space) and promotes a multi-dimensional global site ${ }^{1}$. In that way, a global site (space) becomes a subject of regeneration, and focuses on the problem of global and local identities. The significance

1 Glocalidentity and space imply the ethical integration of local and global identities. In the process of "glocalization", the risks of homogenization ofcultural expressionsand the exclusion of local cultures from the "global network" are reduced. of research lies in the analysis of the role of urban design in securing integrative methods for holistic development of ambient values in the processes of harmonizing horizontal and vertical relations, according to the dynamic of globalization and relatively static relations of local tradition.

On a broader philosophical level, the problem lies in the process of achieving rationality and creating an issue of its universal existence. In that sense, relativization of values raises questions regarding the subject of the regeneration as an affirmation of the existing and creation of new ambient values. On the theoretical level, this paper will discuss the advantages and disadvantages of the two most present paradigms in urban decision-making: rational-comprehensive and collaborative, as well as the role of urban design in integrative processes. The problem of the first paradigm is limited rationality of stakeholders and experts in perceiving the totality of reality, therefore a lesser possibility of generating integral solutions in the urban regeneration process. The problem of the second paradigm can be the absence of strategic approach in generating solutions - responding to temporary problems; as well as the ethical behaviour in the communicative procedure, which is carried out in the process. In relation with different traditions, there is a dilemma regarding the role of urban design, on the relation process-product.

The determinant factor in this dilemma is the rationality procedure carried out in the social context, thereby, the favoured urban paradigm as well. Viewed as a product, urban design treats space as a realization of rationality defined on higher structural levels, through the so-called top-down approach; while in process orientation, urban design is often linked to the collaborative paradigm, the bottom-up approach.

\section{Urban Design as a Path towards Vivid Cities with Historical Values}

It can be said that the historic cities, by their character and essential role, generate durability with the aspiration to eternal existence. But most importantly, the cities contained and conveyed the "motive" of their duration that is to enable the living inside the city, which it represented at every moment of its existence, a prerequisite for rest and duration. If "life in cities" ceased to exist, cities would die by the nature of the law of life, slowly extinguishing, and simply disappearing. In fact, cities would "die".

The main question of this research is what approach, architectural and urban profession should have in relation to historic cities (both in whole and parts) in order to ensure its livability and durability? Furthermore, how to do to make their durability, both physical and material, even more vital, be able to successfully realize its basic function towards eternity. The basic paradigm of the historical cities is defined by following postulates: 
1 City as a physical creation is not holistic city;

2 City without livability loses its reason of existence and duration;

3 City is holistic only if its physical creation develops and continues following the life of its people.

4 The city is holistic only if its physical form develops according to the needs and interests of its citizens;

5 Only integrative approach between physical city form and its living patterns can enable its durability and eternity. (Figure 1)

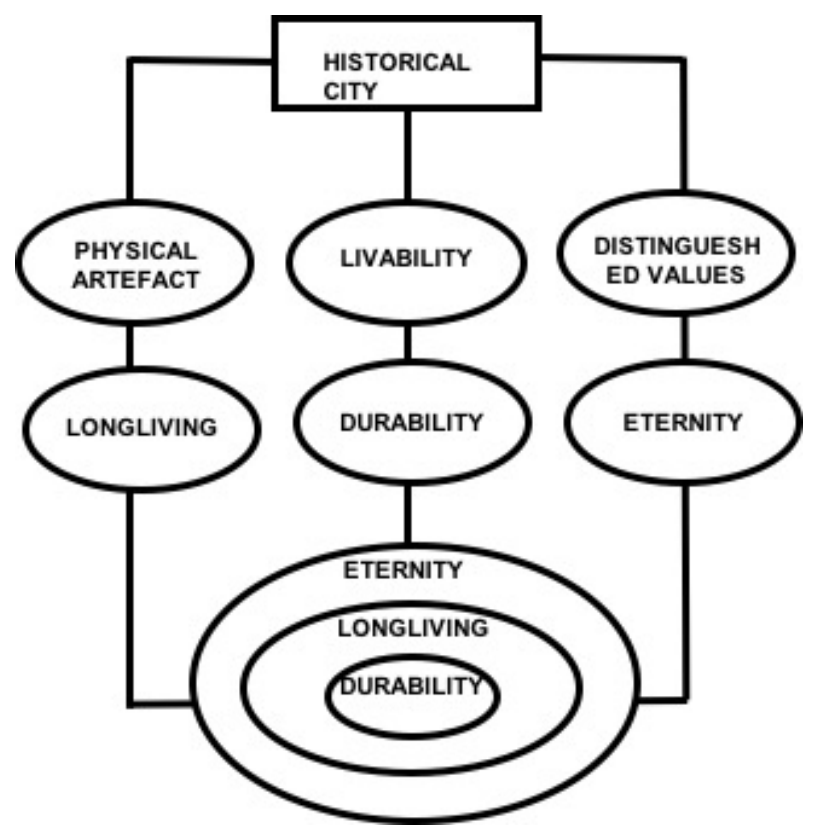

Figure 1. Lifecycle of cities

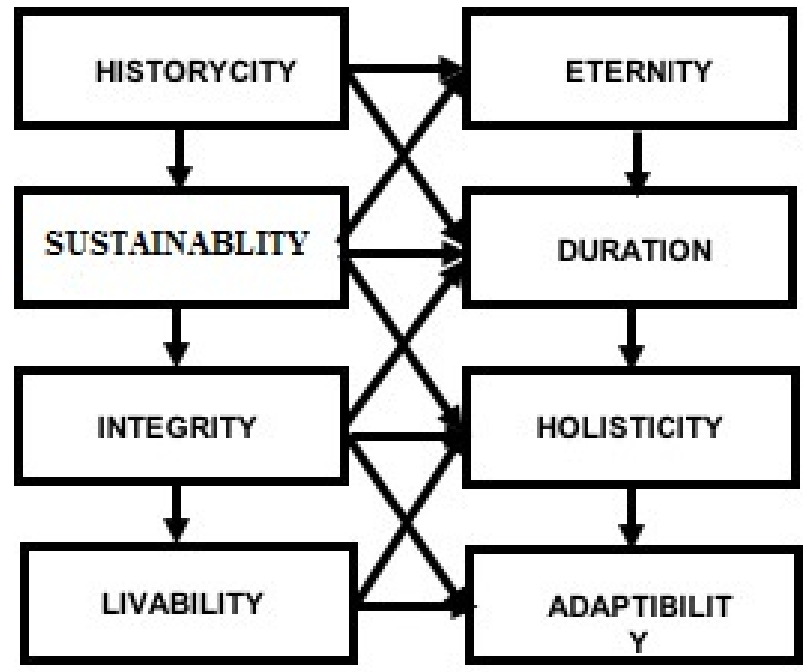

Figure 2. Premises of historical cities

Another question arises: What are the "essential qualities" that we as experts should incorporate in the development of "historical cities" and, besides their "preservation", to start "improving" their existence and duration. This is explained by the following premises:
I HISTORY CITY is a characteristic that speaks on the time when cities were created;

II SUSTAINABILITY is the premise of its emergence and development over time;

III INTEGRITY, ie, more precisely, holistic characteristic of its contents / activities; of the structure (functions, material ...) and forms;

IV LIVABILITY of historic cities over time, which means the constant presence of people in it.

$\mathrm{V}$ ADAPTABILITY of historic cities over time, adapting them to "life" that has taken place in it earlier.

Therefore, this research will focus on the comprehension of urban design as a creative, participative and collaborative process, in which it is possible to create solutions in a holistic relation of multi-dimensional qualities of city place in the regeneration procedure. In perceiving urban design as a creative, socio-spatial process, we would like to point out several interdependent dimensions in which it is created. Firstly, it can be observed as a space of imagination and creation of urban designers, architects, and then it is termed as a subjective-expressive process. In the context of the collaborative paradigm, it represents a socially communicative process, where new relations are established and spatial values are defined in dialogue relations. Understood as a technical process, it is linked with expertise of urban designers and relies more on the rational approach to solution formation. Its third dimension takes place in an interdisciplinary communicative process as a field for analysis and communication of different professional views [3].The above-mentioned process dimensions are intertwined and form a network, making urban design an important factor in integration and communication of different presentations, interests and needs in the regeneration process. "Seen as a process of place creation, urban design integrates different dimensions of space production". [4].

Understood as a multi-dimensional process in which the qualities of place are generated by the participants in the process, uniting the different "images of the world" into a communicative and creative consensus. This raises the question of the ethics of integrity in creating multi-dimensional identity, i.e., a type of communicative process that is practiced in participation. The problem of integrating interests and value choices occurs in risky and uncertain situations that practically always appear in complex urban problems like urban regeneration. This question determines the aim of the process as coherent management of different types of rationality of the participants in the process. This problem, i.e., goal is achieved in theory and, in my opinion, through Habermas' communicative action [5]. The theory has its limitations in the barriers for open communication in the structure of the communicative process. The barriers refer to physical context - mechanical (for example, noise), semantic (like 
incorrect use of words), psychological barriers referring to beliefs, experience and assumptions. The communicative process can be easily manipulated by different instruments of persuasion. [6].

In that sense, we would say that the integration problem amounts to the elimination of barriers in communication. Guided by this assumption, we have come to the conclusion that removing the barriers in the domain of physical context and semantics is ethically justified. However, this poses a question of ethical justification for removing the psychological barriers in the process of communication. Dare we influence the beliefs; analyze differently the experiences, cultural differences, and question the assumptions, prejudices of the interlocutor? In fact, we speak of the process of self-actualization and we support Maslov's opinion that there is a kind of "self" that should be actualized ${ }^{2}$. A human being is not a tabula rasa; it is not a ball of clay or play dough. It is already present, at least as some kind of "gristly" structure [6].Where is the boundary between the ethical and manipulative communication in the process of participation? What are the principles of a sustainable process of participation in the urban regeneration of identity? The problem in integration is actually 'manipulative integration'. The process of integral urban design should transfer the phenomenon of "consensual chaos" into the phenomenon of "consensual identity" (term, T. Mrđenović).

In this process of balancing between subjective realities, rationalization and identity objectification, I single out the barriers of open communication as the key limiting factor, i.e., the positions which are favoured by the instrumental or strategic communicative action, the rational and collaborative paradigm. It is my opinion that both paradigms are on the line of sustainable urban regeneration. The rational secures vertical integration, ethical communication and unification of different global images into a coherent whole, while the collaboration creates a horizontal network through mediation of different perceptions of reality. [4]

Questions are raised regarding the hidden interests, and herein, we shall introduce the game theory by which the communication barriers can be analyzed. According to the classic definition, the game theory represents a "rational mathematical theory that deals with rational decision-making in conflicting and partly conflicting situations" [7]. The games are divided according to the number of participants and outcomes of situations. Regarding number, they can involve two or more participants; and regarding outcomes of situations games

$2 " .$. actualization of self implies that one's experience is total, alive, without selfcensureship (selflessly), with total dedication and fixation. This means experiencing without adolescent self-consciousness. In such a moment of experiencing, a person adopts entire and full humanity." [6]. In a global and network society, Castells speaks of personal and collective identity crisis, where actualization of self is necessary so that individuals could become subjects, groups organizations, and a civil society can be developed [2]. with a zero sum or non-zero sum [7] in fact, games that lead to a compromise or a consensus. The rationale of this theory is based on the assumption that the participants in the game wish to maximize their interest, to make their moves and accordingly choose individual strategies. The game theory, considering that it includes different protagonists and is based on conflicting situations can also be applied to the process of urban decision-making. As the process of urban design includes many participants in the decision-making, it can be said that it represents a kind of game.

On the other hand, if the game is defined as an artistic game of finding a solution for common problems, urban design obtains a new role in the process of sustainable urban regeneration. Then the players, i.e. protagonists, become the participants in the drawing of the common image, representing the factors of creativity. As such, they become sincere in their artistic game, because art represents truth and sincerity. In this game, the image of the future is articulated; giving a common framework of values that are larger than the sum of individual values, the best outcome of the classic game theory. In order for the common image to be drawn, coloured and coherent, the players should play openly, that is, they should be included as active factors in the process of urban design. As the advocates of creativity in the artistic dimension of the urban design process stand out urban designers and architects, who by relying on the intuition, power of visualization and creation of coherent composition, direct and facilitate the communicative process using the collaborative and rational approach. Rationalization, in fact, is necessary so that the elements of the image are brought in harmony with the dimensions, proportions, colours, tonality, light and shadowing. The image created as such presents a consensual solution, carrying with itself a new value.

In the development of the win-win solutions, urban design has an integrating role because through a consensus it joins the scientific, artistic and collaborative approach. The first implies research of facts and past states in order to determine and foresee the future ones, as well as a rationalization of the effects of possible alternatives in the future; rationalization of real problems and valorisation of alternatives. On the other hand, the artistic approach deals with seeking the truth about the real values, which implies an openness and sincerity in approach, while using imagination and the existing state of things in order to make a new value [8]. In the basic definition of the game theory lies the strategic planning of the moves by individual players, while I would say that on the basis of the integral game of urban design is also strategic planning; in which players make their moves to draw a common image of the future. The basis of the game in both cases, in fact, is the strategic planning of moves; while the ways, methods and techniques of their planning differ. 


\section{Case Study: Integrative Game of Urban Design in the Regeneration of Public Space in the Bač Fortress Suburbium}

In the creative process of urban design, we prefer to speak of the factors and advocates of the process. The advocates of the process are certainly individuals that possess a certain degree of creativity, potentials of imagination, visualization, argumentation and objectification; while the factors of the process are protagonists who are interested in participating and contributing to the search for sustainable solutions in an integral way. Additionally, the advocates of urban design are urban designers, who with their creativity can perceive and unite spaces with different traditions, by using adequate methods and procedure techniques. In this chapter, we shall introduce the integral game of urban design as an innovative method for the integration of different rationality types in the process of urban design and urban regeneration.

Methods, techniques and tools of the integral decision-making process in urban design vary in relation to the rationality type, i.e., the degree and type of participation and collaboration in generating the results in a specific decision-making phase. In the context of sustainable and integral urban design, both types of rationality play a significant role in the formation of an integral image of fragmented realities. In different phases through the iterative procedure, they contribute to the integration of different perceptions of complex reality or future. Generally, they differ in relation to the degree of expertise and level of collaborativeness they support. They can be categorized according to the phase of integral urban design they support: (P) Preparation A) analysis of the present, V) Vision, S) Strategy, I) Implementation [9];as well as according to the level collaborativeness: (a) Disciplinary, b) Interdisciplinary, c) Collaborativeness); and according to the type of rationality they support, whether: (a) it improves argumentation, b) improves collaboration and trust-building, c) improves the flow of ideas and information, d) develops creativity, e) raises the awareness level, e) develops identity and space character).

Integral game of urban design is an innovative method and integrates different processes of urban design, such as the subjective-expressive, social-creative, social-communicative, technical-rational, and interdisciplinary. The aim of this method is to develop different types of rationality in a community by an adequate regeneration process and achieving the quality of place through a creative game in the visualization of space. The method is rationalized in the key segments of the process, using argumentative and expert methods. In this way, it creates the future of the place through its spatial visualization, using three-dimensional and two-dimensional presentations, drafts, drawings and text, different expert methods of polling, interviewing, context analyses, morphological analyses, as well as collaborative methods that support argumentation by use of different diagrams such as problem tree and tree of aims and measures. The essence of the urban design integral game is to establish a relation between different types of rationality, as well as between the phases of the planning process. As a method, it implies a continual procedure in the development of social creativity, as well as its rationalization.

In the light of creating the conditions for communicative action in the regeneration processes and integration of reality fragments, the method integrates the advantages and disadvantages of the two most present paradigms in urban decision-making, the rational-comprehensive and collaborative; changing the role of urban design in the integrative processes. The problem of the first paradigm is the rationality limitation of stakeholders and experts in perceiving the totality of reality; therefore there is a lesser probability for the generation of winning solutions and decisions for different dimensions of regenerative processes. The problem of the second one can be the absence of a strategic approach in the generation of solutions, i.e., responding to current problems, without insight into the possible development program-spatial solutions in the regeneration processes. [4]

The method facilitates the practical command of integrating rational-comprehensive and collaborative paradigms in urban decision-making and process oriented urban design, for establishing a relation with sustainable principles of regeneration. The purpose of the method is in establishing the relations between two paradigms. "Position that I stand for is optimistic one, based on the assumption that communicative action can integrate positive and overcome negative aspects of each the paradigm, using creativity as a mean for open communication, flow of ideas and thoughts. Therefore argumentative approach uses creativity to make linkages in strategy making crosscutting both paradigms providing particular identities, interests and needs to be recognized as well as having an ideal picture of development as a coherent whole." [4]

Integral game of urban design has been applied as a method in the Summer School of Architecture in Bač in 2010, in the workshop with the topic Participative Approach in the Shaping of Public Space - the Bač Fortress and its Suburbium. [10] part in the workshop, together with the students of the Summer school and stakeholders from the local community: representatives of the Directorate for Urban Construction, Tourist Organization of Bač municipality, "Centuries of Bač" Fund, Radio Bačka, and the local population. The process of integral urban design was created in such a way that the process proceeded through the following phases:(1) Preparation of the participative procedure, (2) Defining the desired future visioning, (3) Analysis of problems and potentials, (4) Defining strategic objectives and measures for improving 
public space, (5) Spatial solution testing. The method, in a holistic way, has supported different phases of the process, which were built incrementally an integrated into the ambient presented in Figure 12. In that sense, the method has combined different fragmentary methods by passing through the decision-making phases depicted in Figure 3. P - Preparation of participative process is the first phase of strategic collaborative urban design where social profile of all stakeholders should be done as well as choose the right participative methods like mapping stakeholders, nominal group technique, brainstorming, artistic workshops (which was crucial for this case), trainings, etc. V- Visioning can be second or third phase of the process (or not needed at all in urgent situations like flooding, etc.) where chosen relevant stakeholders should create common ie. consensual image of desirable future, defining values they want to promote as well as principles of achieving it. Vision is represented by image, logo and textual description. A Analysis of present is second or third phase of the process, depending on specific situation in the community where problems and opportunities are recognised and clarified by all relevant stakeholders from public, private and civil sector. S - Defining aims and strategies is third of fourth phase in the process where relevant stakeholders define (integrated) aims and strategies for achieving vision or solving main problems. I - Implementation is the last phase in the process where relevant stakeholders define action plan with roles and responsibilities among stakeholders from public, private and civil sector making strong partnerships for realizing their strategies, aims and vision. The following case study will give further explanation on their substance.

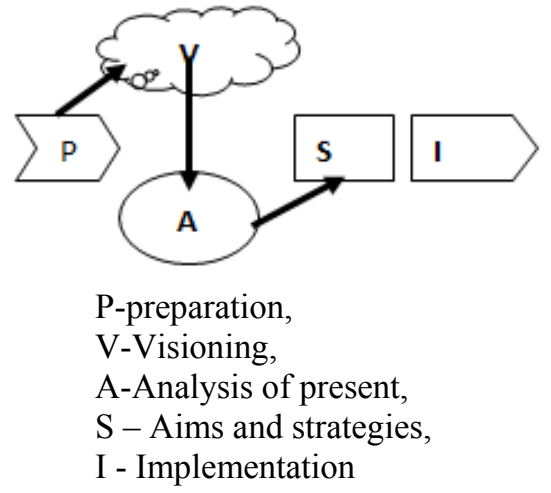

Figure 3. The path of the urban design integral process applied in the case of the regeneration of public space Bač Fortress and its Suburbium

\subsection{PHASE 1: Preparation of participative Process}

The first phase the participative process was carried out by the mentors and students of the Faculty of Architecture in Belgrade who had recorded the existing state on the terrain through the identification of the needs and wishes of the local population (using polls and interviews), as well as through the identification of spatial potentials and development limitations of public spaces (by visiting the terrain and taking photographs, notes and sketching).

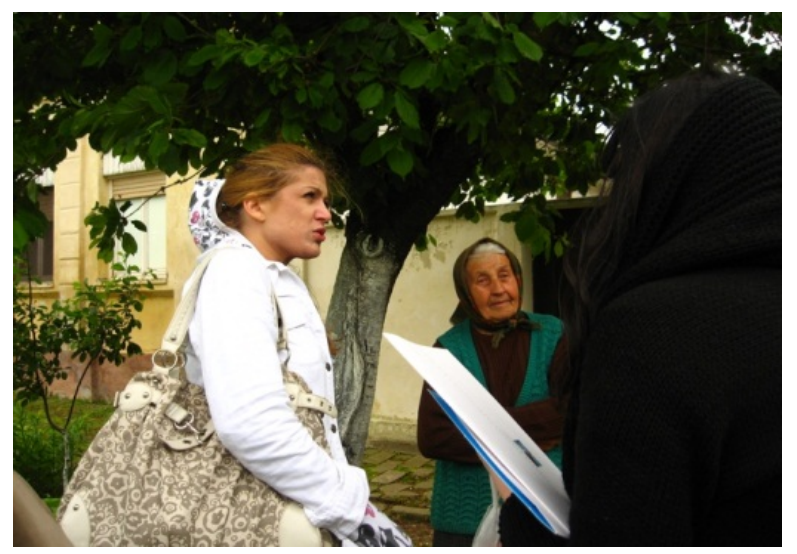

Figure 4. Students of the Faculty of Architecture in Belgrade while doing interviews with inhabitants of the suburbium

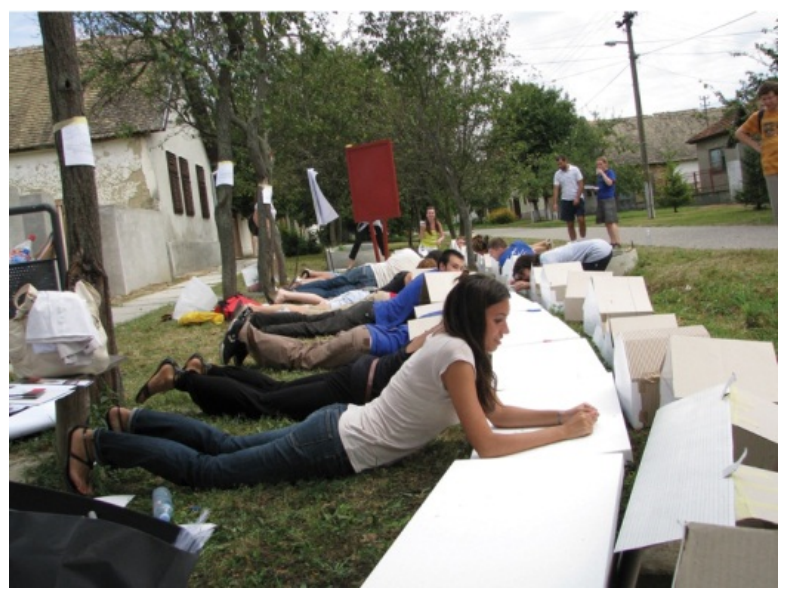

Figure 5. Making mock models of street fronts as the base for creating solutions throughout the entire process, [10]

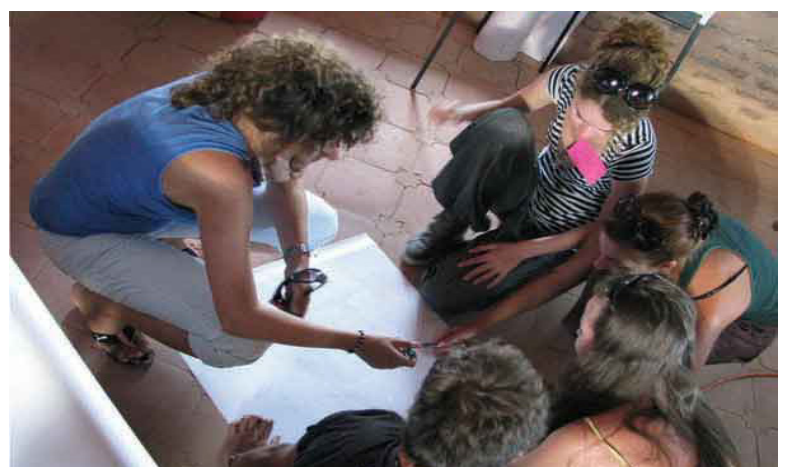

Figure 6. Participants of the Summer school in Bač, during training about participation in the regeneration of protected urban ambients. [10]

The remaining phases of the participative procedure were realized through trainings lasting a day and a half as part of the Summer school of Architecture in Bač [10]. The training was conceived according to the principles of adult education; the methodology and realization were adapted to the needs of the Summer school. The training consisted of seven modules: MODUL 1 - Concept of sustainable 
development and urban ambient of cultural-historical importance, MODUL 2 - Participative planning and forming of urban ambient of cultural-historical importance: integral approach, MODUL 3 - Realization of the integral approach - Defining the desired future - Visioning, MODUL 4 - Realization of the integral approach Analysis of problems and potentials, MODUL 5 Realization of integral approach - Defining integral objectives and spatial-physical dimensions, MODUL 6 Realization of integral approach - Solution creation, MODUL 7 - Realization of integral approach: Spatial solution testing. Within the first two modules students gained knowledge and skills regarding the sustainable approach to regeneration and identification of qualitative characteristics, which are in accordance with the principles of sustainability. The remaining phases of the qualitative characteristics of places were realized together with the above-mentioned stakeholders.

\subsection{PHASE 2: Visioning -Creating Desirable Future}

In the visioning process, among the participants besides the students, were also relevant stakeholders from the local community: inhabitants of the Bač Fortress Street, the representatives of the Tourist organization of Bac municipality, "Centuries of Bač" Fund, Radio Bačka. The process was supported by brainstorming and nominal group techniques, as well as by creative techniques of visualization and text. The vision was formulated on several levels: through key words, the slogan, drawing-image and a sentence that describes the vision more elaborately.

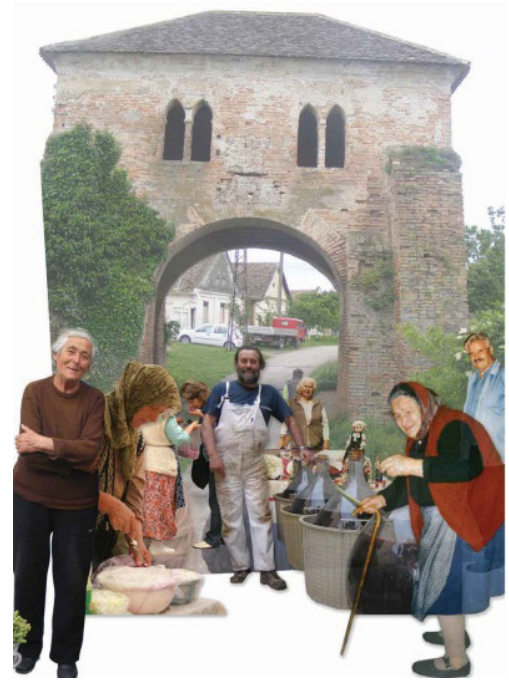

Integral vision of the suburbium's
inhabitants:

THE STREET OF SMILING FACES We want our settlement to develop in a way of active promotion of its cultural values with improvements of quality of our life. We want to be active participants in the development cultural manifestations and promotion of its past life and values.

Figure 7. Integral vision of the inhabitants of Bač Fortress Street [10]

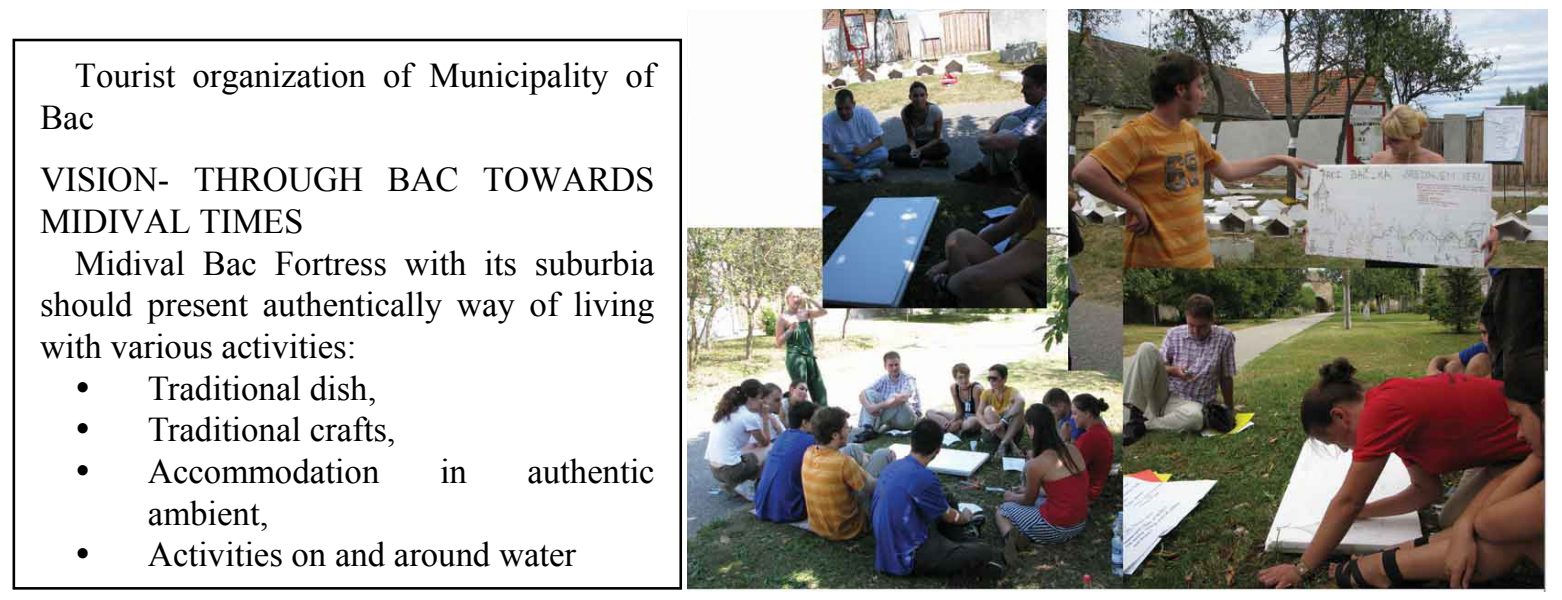

Figure 8. Integral vision of the Tourist organization of Bač municipality: THROUGH BAC TO MIDIVAL TIMES 
RADIO BAC

\section{VISION - TOWER WATCH}

- Reconstruction of the midival way of living,

- Traditional dish,

- Alternative medicine,

- Tourist participation in traditional crafts,

- Gate as border of presence,

- Story of founded knight

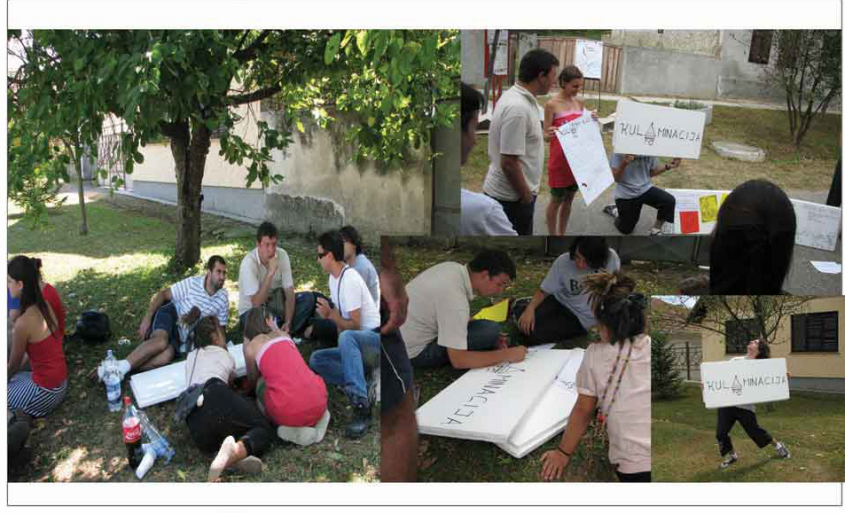

Figure 9. Integral vision of Radio Bačka: TOWER BRIDGE FROM PAST TO PRESENT

Fond Centuries of Bac

VISION - BACHOOK

- Multiculturality,

- Livable suburbium,

- Traditional crafts,

- Artaction of star architects,

- Richnes of flora and fauna /egology

Figure 10. Integral vision of "Centuries of Bač" Fund: MULTICULTURAL LIVING BAC

\subsection{PHASE 3: Problems and Potentials}

The following phase of the process was the identification of problems and potentials that hinder or facilitate the realization of the vision, by using brainstorming techniques. The recognized problems and potentials have been grouped and classified by hierarchy using the problem tree technique, which has facilitated their rationalization and the realization of cause-and-effect relationships.
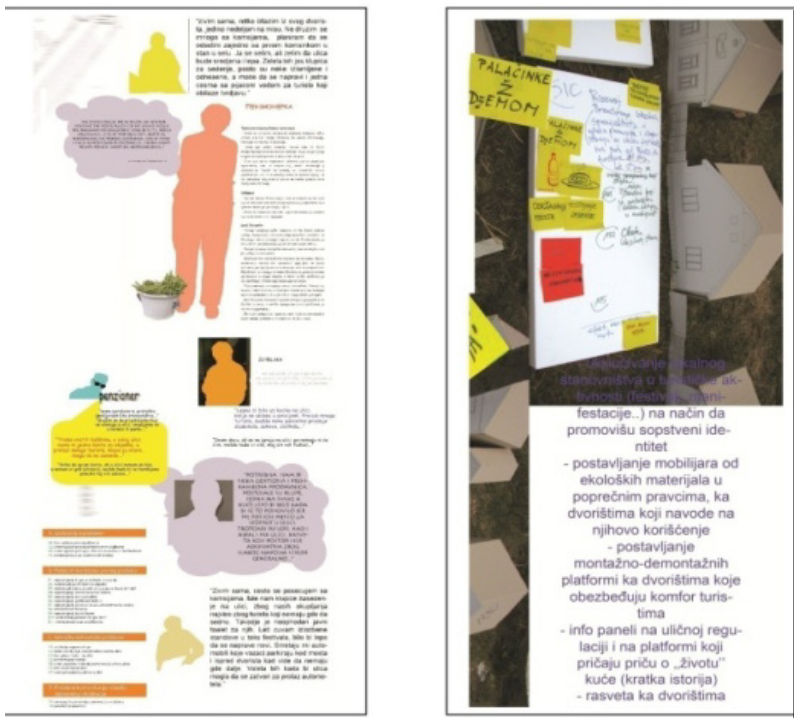

Identification of problems and potentialities was done using different methods: interview with inhabitants, brainstorming and nominal group technique with stakeholders. They recognized main problems as lack of knowledge on how to reconstruct their houses in line with protection, lack of activities in suburbia, lack of promotion of values, etc. The figure is an illustration from the workshop

Figure 11. Identification of problems and potentials 


\subsection{PHASE 4: Integral Objectives and Measures}

The problem tree served to formulate the strategic integral objectives and spatial-program measures that contribute to the realization of the objectives. In this iterative procedure, individual visions have been redefined so they could be adapted to real development needs and potentials.

\subsection{PHASE 5: Spatial Presentation through the Integration of the Previous Phases, Different Global Images, Values and Interests}

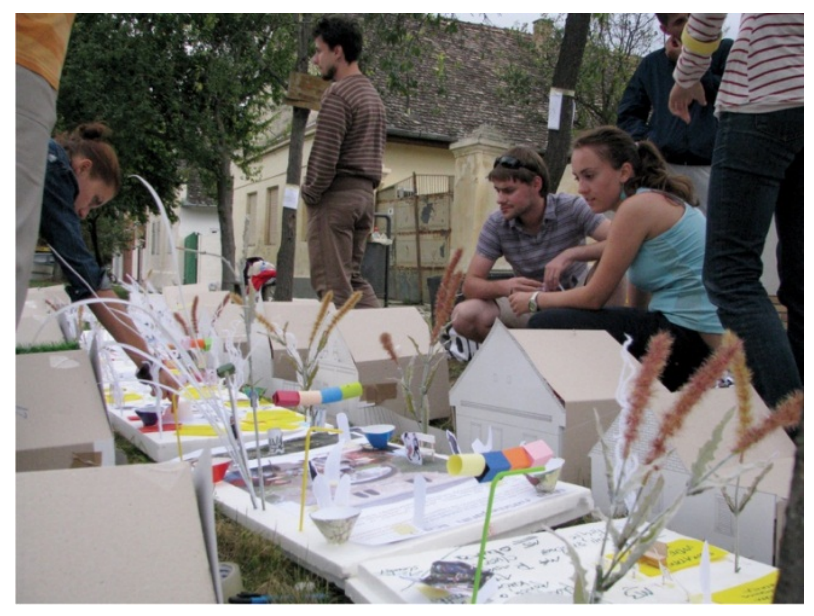

Figure 12. Integral presentation of urban design strategy for the regeneration of Bac Fortress Street / Mimicry model of the street [12]

As the end result, with the creative and rational development of the mock model of the existing street fronts, different phases of integral urban design, types of rationality and different global images were combined into a coherent future. That way, an integral place with a specific identity was designed, while respecting and affirming the inherited values, including the local population and other relevant stakeholders in the development of cultural tourism and commercial sector.

\section{Conclusions: The Role of Urban Design in Ensuring Principles of Vivid Historical City}

The research implies that the preservation of historical cities cannot be based solely on the protection and preservation of their physical creation, that the "monumental feature" of the time in which they were created to remain. Also, the "transformation" of historical cities into certain exponats, creates an illusion that the city as it is seen at the time has always been like it. The documents depicted that the epochs through which the city was passing were constantly changing and adapting city over time.

The preserved physical facilities of cities turned into museum exhibits have always demanded great investments in order to maintain their historicity or have ceased to be of interest in people (except for scientific researchers) that made them never - reasonable in time. All of these reasons reflected in time on their abandonment, neglect, the gradual extinguishment of the museum function, and led to the gradual phase-out of cities gradually, while continuously providing (in ideal conditions) the preservation and regeneration of their "exponential splendor".

In this line, the research showed that process oriented urban design is significant in the process of urban regeneration for two reasons. Firstly, it can affirm the existing or create a new identity, by using its artistic, subjective-expressive and interdisciplinary dimension. Secondly, in cases where there are no inherited ambient values, there is a greater possibility of a consensus being achieved in its socio-communicative process through a creative environment for "hard and soft infrastructure" [11]. We can conclude that, from a theoretical standpoint, process oriented design has a greater possibility for creating an integral place, i.e., integral ambient values in the regeneration process. Therefore, this kind of process integrated above mentioned model of preserving non-renewable values and bringing back into life the values that are lost or forbidden as well as introducing new values that are upgrading preserved ones enabling contemporary life to create integrated place; making these areas integrated on physical, socio/economic and cultural level horizontally and vertically.

As it was shown in the case study, the result of this research refers to the description of the specific method of integral game/play of urban design, which has combined the different types of rationalities in the participation process, while realizing particular interests into a coherent ambient of a higher value. Thereby, the framework for the urban regeneration of the Suburbium is defined by creation and integration of different development visions and their transfer into strategic alternatives and measures through evaluation in relation to problems and potentials. The advantage of this method, compared to the one-dimensional one, is that it combines different types of rationalities and facilitates horizontal and vertical integration, i.e., the creation of multi-dimensional places as the subject of sustainable urban regeneration. "Urban design, considered as decision making and communicative process, as well as creative imaginative and rational can provide framework for sustainable regeneration." [4] This means new rationality that is in line with modernism and cosmopolitan culture.

Therefore, we can derive several principles that integrative urban design game should follow in order to trace path from museum to vivid city:

1 PRINCIPLE - Continuously, ensuring the preservation, maintenance and restoration of physical creation, functions. It is also important to preserve and maintain the museum functions of the display and description of the old vectors on which the city rests; 
2 PRINCIPLE - Provide: new opportunities, new (occasional) content and activities to increase the level of attractiveness such as: 1. Organizing occasional events that resemble earlier times: - for example, the time of knightly martial arts 2 . Organizing modern activities such as: e.g. artists' colonies, music manifestations, meetings of "devotees". 3. Organization of mass "fair" manifestations: e.g. fairs, fairs, religious gatherings;

3 PRINCIPLE - Introduction of possibilities of accommodation capacities for different tourist needs, such as: residential towers, exclusive nights, apartments for renting, hotel capacities within the existing physical structures;

4 PRINCIPLE - To re-populate settlements of cities: Residents (owners) "old people", employed "residents" who work on the maintenance of cities, planning, providing apartments;

5 PRINCIPLE - Enabling "minor" interventions to the existing physical creation: 1. Filling existing housing structures with communal systems: construction of sewage and water supply systems, introduction of energy - power networks, maintenance systems. 2 . Renovation of interior spaces, primarily residential 3. Edition(greening) of open spaces, on the principles of the time in which they were created;

6 PRINCIPLE - The minimal "over-construction" of the existing physical creations on the postulates of the time in which they were created: the revival of the parts of the city that were collapsed, and which existed earlier, and the effective "extension" of certain circuits on the principles of clarinet time these circuits were created.

\section{REFERENCES}

[1] Elin, N. Postmoderni urbanizam. Beograd: Orion.Elin, N. 2004.

[2] Castells, M.The Power of Identity.Zagreb: Golden marketing.2002.

[3] Madanipour, A. Design of Urban Space: An Inquiry into a Socio-spatial Process. Baffins Lane, Chichester: John Wiley \& Sons Ltd. 1996.

[4] Mrđenović, T. (2011). Integrative Urban Design in Regeneration - Principles for Achieving Sustainable Places. Journal of Applied Engineering Science, 305-316. 2011.

[5] Habermas, J. Filozofski diskurs moderne: Dvanaest predavanja. Zagreb: Globus.1988.

[6] Maslov, A. O životnim vrednostima. Beograd: IP Žarko Albulj.2001.

[7] Pavličić, D.Teorija odlučivanja. Beograd: Ekonomski fakultet. 2004.
[8] Day, C.Consensus Design: Socially inclusive process. Oxford: Architectural Press. 2003.

[9] UN-Habitat, \& SIRP. What is participatory planning? Belgrade: UN-Habitat. 2005.

[10] Mrđenović, T. (2010, Avgust 27). Radionica: Participativni pristup u oblikovanju javnog prostora - Podgrađe tvrđave Bač. Letnja škola arhitekture u Baču 2010. Bač: Klub mladih arhitekata.

[11] Healey, P. Collaborative Planning: Shaping Places in Fragmented Societies. London: MACMILLAN PRESS. 1997.

[12] Mrđenović, T. Patent:Integrative game of urban design 01. Beograd.2010

[13] Ralevic M., Modeling of urban process, Faculty of Architecture in Belgrade. 2006.

[14] Ralevic M. Milanovic a., Study of protection of cultural heritage of historical city of Kragujevac, Heritage protection of Kragujevac and Faculty of Architecture in Belgrade. 2003. 